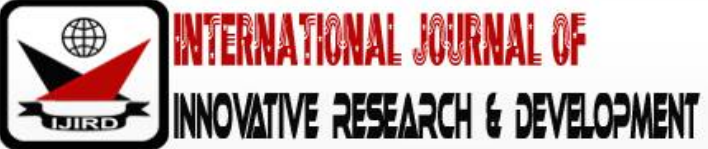

ISSN 2278-0211 (Online)

\section{The Role of Social Media Adverts and Online Trust in Organizational Growth and Profitability in Ghana: An Empirical Review}

\author{
Obrien Nunyuie \\ Master Student, School of Management, Jiangsu University, China \\ Fan Mingyue \\ Associate Professor, School of Management, Jiangsu University, China
}

\begin{abstract}
:
The development of social media platforms was targeted at enabling individuals around the world to connect and interact without physical contact through the use of technology devices. Since its introduction, social media has successfully created a whole great population of netizens on different platforms such as Facebook, twitter, and Instagram among others. Recent times have seen a surge in companies across different industry take their advertisements on social media to keep up with the trend: and unlike the past, most social media platforms have an option to create a page instead of the usual personal account. With the commitment-trust theory(CTT), social capital theory (SCT), trust building theory (TBM) and media richness theory (MRT) as theoretical foundations, this paper adopted an empirical method to investigate how social media adverts and online trust has translated into profits for companies across the world. It does this by reviewing theories and documented cases of social media adverts and its results in Ghana. Based on the reviewed best practices and theories of trust and social media, a comprehensive model is developed to guide Ghanaian firms in building trust and advertising online the grow in profits. At the end of the study it is revealed that social media has contributed an essential element to online marketing more than any digital tool has ever offered; hence companies who are able to find novel and effective ways to catch audience attention and instantly convert platform visitors to customers by means of conversation and brand promotion are able to secure a leading market position over competitors. It is also found that Facebook is the leading platform for effective adverts in Ghana followed by Instagram and Twitter respectively. It is therefore concluded that at the centre of an organizational growth and profitability driving social media advert are engagement with stakeholders, branding, and learning.
\end{abstract}

Keywords: Social media, social media advert, trust, organizational growth, CTT, SCT, TBM, MRT

\section{Introduction and Background}

Over the past decade, social networks have evolved so rapidly and currently utilizes digital media; it is hard to wonder how social networks started considering how fast it has emerged (Edosomwan et. al,2011). In light of this, Carton (2009) submits that many technologies have been developed to make communication easier; this coupled with the widespread technology acceptance could account for the growth and influence of contemporary social media. Edosomwan et. al, (2011) noticed that the early 2000's saw the springing up of many social networks which increased interaction among individuals and groups with common interests. Junco, Heiberger, and Loken (2011) agreed to this by intimating that 2004 and 2005 saw the sprout of popular names like Facebook, Dogster, YouTube, and Mixi among others. These platforms paved the way for the arrival of Twitter, Instagram, WeChat, and WhatsApp. Nowadays, these platforms are generally called social media. Mayfield (2006) cited in Veil, Buehner and Palenchar (2011) opines that trust is at the center of social media is communication; also, it provides a platform for people to connect, take part in social discussions, and freely share their views. Social media was described by Veil, Buehner, and Palenchar (2011) at that time as 'new media' enables individual to become private sources of information by putting up their opinions and understanding of issues (Marken, 2007). Irrespective of the relevance of social media, it has been criticized on variable and enormous grounds. In the words of Carr (2010), 'For me, this is almost as important as climate change. Whilst of course it doesn't threaten the existence of the planet like climate change, I think the quality of our existence is threatened -and the kind of people we might have in the future'. Keen (2007) was certain that social media is gradually damaging our thinking, society, and culture.

In all these descriptions of social media and networks, one key thing runs through as its core mandate and that is communication. Isaacs (2014) noted that, social media has a definite effect on communication and this cannot be overlooked. Trust is very important in communicating especially when the environment is uncertain (Ma et al, 2009). While communicating, it is important to build trust; because it is key in many relationships and helps reduce costs and 
risks and as well bring progress (Putnam,2000; Uslaner,2002). Putnam believed that trust is a dyadic concept while Uslaner argued that it is a virtue learned in childhood. This could suggest that for communication to be more effective, it goes beyond the medium being used and involves the need for trust.

The term 'social media' has become a household name in our contemporary era as many social networking sites like Facebook, Instagram, twitter and WeChat among others have been developed over the years. The obvious trend a few years back was a massive usage of social media on the individual level for communicating and meeting new people; however, the trend has changed as organizations have also joined in. Boyd and Elisson (2008) defined social media as 'a platform to create a profile, make explicit, and traverse relationships'. Manning (2014) also views social media as new forms of media for interactive participation which can he categorizes into the broadcast age and the interactive age. The broadcast age is mainly the traditional form of social media where an entity like a radio station or newspaper publisher disseminates information. However, the arrival of the digital technologies and phones saw the birth of the interactive age which makes it possible for one individual to communicate to a huge number of people and possibly get immediate feedback. Social media can be viewed from different perspectives but in terms of advertisement, it is considered a market space (Yadav et al,2013) which allows users and sellers to communicate in sophisticated ways (Hennig-Thurau, Hofacker, and Bloching,2013). Generally speaking, social media advertising in the organizational setting involves using digital media networks to market products. Social media has taking over society in a very rapid fashion; hence has attracted many organizations to use social media as a platform to advertise its brands (Gallaugher and Ransbotham,2010) as it enables them interact with consumers in a more collaborative way (Thackeray et al., 2008). It is important to note that, social media has changed how consumers think (Mir and Zaheer,2012), hence the need for organizations to bridge the gap if they must grow in profitability.

It is projected that in the future social media technologies will virtually rely on company-company generated information and individual-individual generated information; this will heighten competition and rivalry (Korenich et. al,2013): this prediction in 2013 is almost a reality in today's world.

Information systems as a field encompass studying information technology and how it impacts individuals, organizations, and society (Lucas Jr et. al, 2013). Social media happens to be one of the most powerful and useful advancements in information technology in recent times (Kapoor et al, 2017). Social media has not been researched into a lot with focus on advertising linked with organizational growth, at best trust, communication, and social vices are explored alongside social media.

On this basis, this paper seeks toexplore the role of trust and social media marketing on organizational growth and profitability in Ghana elucidating the key factors in communication that influence trust and determinants of trust on social media among other critical areas drawing on the structured literature review model by Kitchenham et al. (2009), trust-communication theories, and models.

\subsection{Methodology}

The methodology of this paper is two-way; a comprehensive approach to gather relevant data for analysis. The first part of the methodology is hinges on a systematic and rigorous literature review under the themes of social media, trust, organizational growth and profitability, global challenges of social media trust advertisement, threats to organizational growth, and existing theories explaining trust. The key areas of focus are on the methods used in these papers and their findings which provides a solid ground for critical analysis and conclusion. The second part of the method relies on data from documented case studies of firms in Ghana that have used social media marketing, the advertisement strategies used, and how this has helped them grow in profitability. This indicates that the paper is mainly dominated by secondary data and stringent triangulation to enable reliable conclusions to be drawn through empirical review. The study also recommends strategic approaches to social media adverts by developing a novel model to enhance organizational growth and profitability.

\section{Literature Review}

\subsection{Theoretical Framework}

The concept of trust has been studied across many disciplines in both academia and business practice hence the existence of variable and enormous definitions of trust (Hsu, Chang, and Yen, 2011). In the same vein, a number of theoretical models have been developed to explain how trust is built. Moorman, Deshpande, and Zaltman, (1993) developed a framework which classified the development of trust into three stages namely antecedents, process, and outcomes where antecedents refer to the key determinants of trust. This framework emphasizes that the main determinants of trust are individual and organizational characteristics.

There is also the Trust building model (TBM) proposed by Mcknight, Choudhury and Kacmar (2002) to opine that information quality, reputation, informed risks, and organizational factors determines trust. Other researchers have also adopted the Commitment-Trust Theory (CTT) to expand knowledge on the factors that determines trust. Here, trust is determined by shared values, opportunistic behavior, and communication (Morgan and Hunt,1994). It is important to mention that these theories are used mainly for person to person and organization to person trust interaction and hence is applicable for this study. However, the aforementioned theories must be juxtaposed with the Social Capital Theory (SCT) to fully meet the purpose of this study. The Social capital theory intimates that people gain resources from social interactions (Putnam,1995). This theory has become more used in recent times in analyzing issues relating to users on online platforms. This is attributable to the fact that, it encapsulates features that enables users to enjoy benefits like employment, influence, power, market growth, reputation and information among others. The Social Capital Theory has 
therefore been used by various researchers to investigate issues like information exchange, civic engagement, and knowledge sharing (Aslam, Shahzad, and Ramish,2013; Koranteng and Wiafe ,2018; Warren, Sulaiman, and Jaafar,2015). Since trust is one of the dependent variables of this study, the SCT is suitable because it explores social relations. The underlying connections of the above theories with this paper is that, trust must first be built between individuals and the company if social media adverts must be followed up at all by customers to grow the company's profit.

\subsection{Understanding Trust and Social Media}

The concept of trust has been variously defined in a plethora of researches, however there is no single generally accepted definition of trust (McEvily et al., 2003). Ebert (2009) categorizes interactive relationships that breed trust into: trust between individuals, organizations, and between a person and an organization. For this paper, the focus is more on trust between individuals on social media. Interpersonal trust has been found to be generally incorporeal and easily broken (Savolainen, 2011). Various authors have shared their views on trust, some of which agree and disagree. Putnam (2000) views trust as a reciprocal concept which is developed through cooperation with others. In the view of Uslaner (2002), trust is not built based on cooperating or associating with others, but it is virtue (moral) that is learned from parents. A sharply contrasting view is brought up by Rothstein (2003) who looks at trust from the perspective of leadership. He opines that level of trust is a function of good governance.

Juxtaposing trust with social media, Putnam(2000) even though with little evidence intimated that social media cannot create trust because it requires lots of time and does not have an element of one on one meetings which limits interaction. This view is in tandem with the findings of Rheingold (1993)which criticizes social media as untrustworthy on the grounds that fake accounts are created to extort vulnerable individuals. Anderson and Rainie (2014) reports that, recent scandals in theUS exposed some government surveillance and this has caused the government to take actions to further protect its information. The consequence for digital social media is that, trust level is reduced or lost all together. The above views are contrary to the assertion of Hakansson (2015) who believed that digital social media affects trust positively because information is shared easily and at a lower cost than in personal interactions especially advertising and reaching out to customers. The central idea to him is communication. Calefato, Lanubile, and Novielli (2015) also investigated the role of social media in building trust and found that social media plays a key role in building affective trust by ensuring affective commitment.

However, Uslaner (2002) maintains a neutral stand on the effects of social media on trust. He intimates that social media has no effect on trust; that is, being registered on social network in no way influences trust but rather it is a virtue learned from home.

\subsection{The Concept of Social Media Communication}

In the not too distant past, physical presence was key to effective communication but thanks to innovative technologies and globalization, how human think and communicate has become much easier and reliable. Social media connects individuals and organizations across the world to interact in a manner that is independent of time and place (Brown,2009). Social media gives lots of power to users because a mere click can send information to the whole world from anywhere (Talpau,2014). Bertotet al., (2012) argues that even though information can be directed to a particular person on social media, it is practically almost impossible to know who post the information. It is also very difficult to control the spread of information on social media as anyone can freely express their discretion on issues and share for others to see. Social media is applied in business (customer service, exhibiting new products, and exclusive opportunities) and building friendship or affectional ties with new people. Baruah (2012) explained that social media combines web and mobile technology to foster communication. This means a smart phone and internet are the main requirements for social media usage. All social media platforms like Facebook, twitter, WhatsApp, and WeChat just to mention but a few are widely used for communication (personal or group chat). Social media is considered powerful because it enables online sharing of information and knowledge especially in schools. However, communicating on social media comes with the risk privacy and ethical issues. Other forms of social media include blog post and social bookmarking. The above descriptions make it evident that to collaborate effectively online, social media is currently the best option especially for global broadcasts.

\section{The Correlates of Trust and Communication on Social Media}

Social media presents an online platform for people and groups to communicate without the need to meet. Many researchers like Putnam (2000) and Uslaner (2001) have argued that, for there to be trust there must be interaction (communication). In Putnam's view, this interaction must be continuous to breed reciprocity of trust; while Uslaner also perceives interaction as communicating with parents to get the virtue of trust. This is an eye opener to the fact that, trust is built over time through communication. In essence, users of social media tend to trust each on information they share and transactions based on results of first interaction. A plethora of research indicates that building trust is intertwined with risk taking; for example, paying for a product online and trusting it will be shipped. Grazia et al., (2015) Elucidates further on trust building by adding that, trust is a function of transparent, precise, and effective communication between both actors. This submission indicates that, high trust requires a certain level of quality in communication. The next paragraph explains the antecedents of trust on social media and factors within communication that affects trust.

Das and Teng (2004) explains trust from three angles including antecedents, subjective, and behavioral trust. An individual's state of psychology describes his subjective trust while trust antecedents are considered the contextual effects that results in subjective trust. Behavioral trust results from subjective trust. These researchers are of the view that trust is first built on perception prior to any interactions with the other party. If a relationship is established the trust becomes knowledge-based (McKnight et al., 2011). In view of this, Gefen et al., (2003) intimates that knowledge-based trust is 
influenced by familiarity. This points to trust propensity as another important antecedent of trust because it determines whether a person will trust or not.Hamalainen (2015)opined that relationships and personal characteristics play an effective role in building online trust; even though the characteristics of the social media platform does not influence trust, it is key in forming the relationship in the first place.

\section{Results and Analysis}

\subsection{Social Media Advertising and Organizational Profitability}

In contemporary business, effective networking is a fundamental for organizational growth and profitability (Kelley et al., 2010). Macnamara and Zerfass(2012) describes social media use by companies as a way of balancing strategy, openness, and management. Social media platforms have become effective tools for firms today and has rapidly changed organizational communication and public relations (Parveen, 2012) hence creating a more interactive and collaborative based relationship between organizations and their customers. Kim and Ko (2011) assets that organizations use social media as a tool for marketing and advertisements, customer relationship management, and branding among others. Adverts on a social media platform like LinkedIn helps organizations to grow by exposing them to wider pool of talent when jobs are advertised (Van Dijck and Poell, 2013; Van Dijck, 2013).

From an empirical view, fierce global and local competition puts organizations on their toes to be more innovative (Holsapple and Singh,2001). More so, the rise of web 2.0 which is also called social media puts more pressure on organizations to remain relevant as it has been described as the new wave for profit maximization (Faraj et. al, 2011). In spite of this, Joshi et. al (2010) argues that, these claims do not provide a clear-cut basis for understanding how social media builds organizational intellectual capital, hence profitability.

Nyambu (2013) found that, majority of companies who use social media advertisement experience development and growth in profitability. Specifically, it helps organizations get first- hand information of consumer views on products and services via comments option in order to further improve to suit consumer requirements (Tung,2012). Meeting consumer requirements on a consistent basis results in maximized profit levels and customer loyalty.

Moreover, organizational growth and profitability which has been almost elusive is now a dream come true with a heavy investment into IT and social media advertisement (Yao, Sutton, and Chan,2009). Social media breaks barriers marketers usually are unable to. Icha Oyza et. al, (2015) also reported the resurgence of social media in business and how it has moved from simply creating awareness of products and services to interacting and collaborating with customers which has recorded tremendous organizational growth across the world.

Notwithstanding all these great benefits of social media advertising for organizational growth, it still comes with certain challenges; a paradigm which hasn't been very well explored. This paper therefore unravels the dark side of social media adverts for organizations linking them to consumers in general.

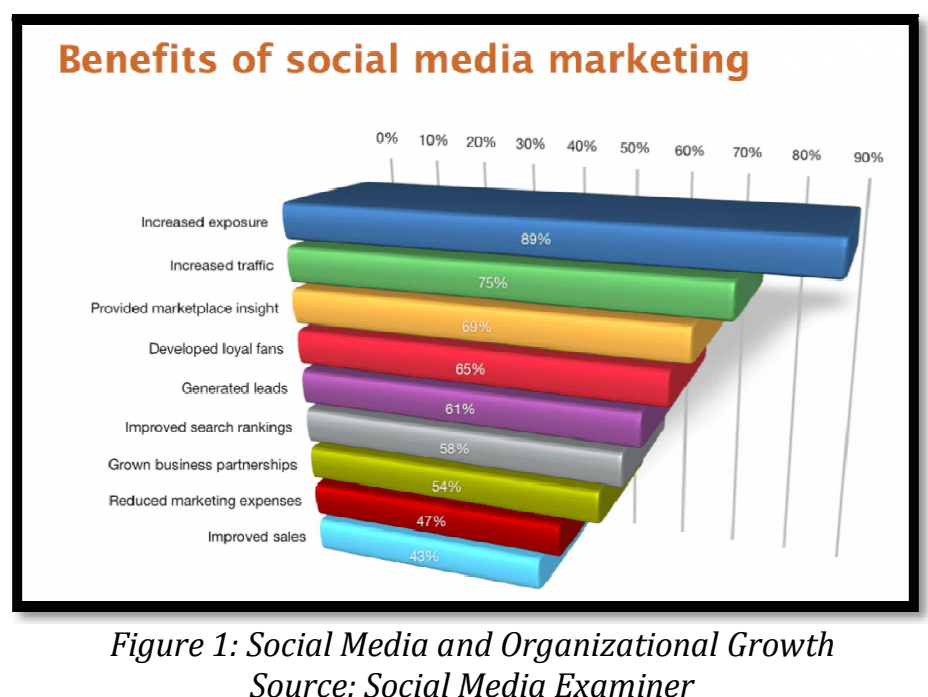

\subsection{Challenges of Social Media Advertisements}

Consumer use of social media for consumption-related activities has greatly increased in recent times as organizations have made it easier through social platforms to have a direct interaction with customers. This rapid development according to Hofacker and Belanche (2018) doesn't only present organizations with opportunities by making its product known through information sharing but also great challenges for marketing executives.

First, there is an issue of the social media platform used for advertisement by an organization and how credible (anonymity and richness of information) consumers think it is. This raises an issue of trust. Kaplan and Haenlein (2010) therefore suggests a critical analysis in choosing a social media platform and even develop their own applications: they stressed however that the success of this depends a lot on involving employees. The challenge has been that, most organizations are unable to choose the appropriate social media platform and managing it holistically enough to win more customers. 
To elucidate further, firms are also confronted with the challenge of needing highly skilled employees to manage social media platforms and interactive tool which may not be readily available. For example, Lorenzo et al., (2013) studied retailers in Spain and found that social media use depends a lot on the size of an organization: huge companies use social media for branding purposes while small firms use it for providing customer service.

In this era of ubiquitous social media networks, information flow is easy and 'liquid'. That is to say unlike goods and services, information trading brings about liquidation of the economy hence a drastic cut in cost. The problem however is with constant network attack by hackers and database trade (Fernandes et al.,2014) and this keeps companies on their toes to take network security measure which in most cases turns out capital intensive (both human and financial capital).

Research also shows difficulties organizations face in managing the reactive market in the face of large volumes of information generated on social media via different devices (Belanche and Casalo,2015). There are billions of social media users over the world and some users who are not the target market segment of an organization may as well chance on its information. This huge volume of information is called Big data. The amount of traffic generated by users online cannot be controlled by a firm: it can only monitor its brand related content. This is a daunting task even for highly skilled employees as not all consumer reviews can be factored into decision making and this can have consequences for organizational growth and profitability.

Consumer behavior has always been considered an avenue for solving marketing problems (Blackwell, Miniard, and Engel,2001). The situation is however today with the rife nature of social media which enables a pre and post consumption review by consumers and this needs to be integrated into the traditional channels to fosters better management (Flavian, Gurea, and Orus,2019). This is described by Hofacker and Belanche (2016) as the challenge of 'adjusting to the changing purchase journey'.

The above elucidations of challenges organizations encounter in their bid to remain competitive in the market in this digital shows a myriad of issues which must be critically considered if an organization must grow in profitability.

\subsection{Threats to Organizational Growth}

Even though there are strengths and weaknesses in every endeavor, it is quite surprising the level of threat a business is exposed to for using social media in its operations. Some researchers (Boyd,2011; Clarke,2010; Okeffee and Clarke,2011) extensively highlights the privacy threats social media usage poses at the organizational and individual levels. More so, Clarke (2010) emphasizes that inappropriate disclosure of organizational information does not only gives rivals competitive edge but also tarnishes organizations image and slows down growth and profitability.

Communication is the main part of any business as it encapsulates sales, marketing, and strategy among others. The new trend of social media requires lots of technological knowhow and financial investment to remain relevant. This situation greatly threatens traditional companies which predisposes them to collapse because they may not be equipped with the needed human and financial resource.

Hutchings (2012) ; Picazo-Vela et al, (2012) ; and Bertot et al., (2011) discussed the threats of legal policies and regulations of social media usage and highlights the need for firms to abide by rules in terms of content and especially privacy to avoid sanctions of being closed down and losing customer base.

Also, internet scams by unscrupulous individuals (e.g. malware tiny links and URLs), leaking of data is very common things done by individuals, employees, and business \& organization. This could lead to legal problems for employees and organizations (Everett,2010) some of which means huge fines which immediately destroys the financial basis of the organization and makes it unable to operate.

\subsection{Barriers to Building Social Media Trust and Mitigation Techniques}

The emergence of social media has brought some tremendous benefits to its users. However, enjoying these benefits could get clouded by some challenges or barriers. Wood and Khan (2016) identified privacy, legal, and security risks as major barriers to social media usage both for interpersonal relations and organizations. It is emphatically stated that poor social media strategy and lack of security antidotes negatively affects businesses.

Buehrer et al., (2005) identifies that some barriers of social media usage and consequently trust building are related to lack of resources (smart phone and internet connection costs), unfamiliarity with technology, bad views about the usefulness, and time and training. These barriers to social media usage threaten an attempt to build trust because there will be no first interaction at all for trust to be built.

\subsection{Security Issues on Social Media}

The enormous data and large number of social media users makes it very easy for illegal and fraudulent activities partly because contemporary generations have more trust in online sources (Ajami et al., 2011). Social media security technical risks generally include privacy risks, security risks, and anonymity risks among others. All these issues affect the users' and company privacy and breaks trust for using the social media network. Organizations must also look out for fake articles that may hurt its brand. Maintaining ethical standards is also an essential aspect of social media marketing.

\section{Cases of Social Media Marketing in Ghana}

This section provides an array of case studies and surveys on the utilization of social media marketing by various companies in Ghana and their outcomes on organizational growth and profitability. This provides a concrete basis to analyze and conclude on the data. 
In a case study conducted to assess how social media marketing affects the performance of Triumvirate Environmental (a company that is focused on creating safe work environment for developing solutions to combat hazardous waste in Ghana), it was found that even though the introduction of Google AdWords was not profitable as expected, the introduction social media via on blogs, Twitter, and LinkedIn boomed the company's website traffic and online advertisements which in all translated into \$1.2million (Bordnar, 2010).

Dzisi and Ofosu (2014) conducted a survey to understand the relationship between strategies of marketing and the performance of small medium enterprises in Ghana. The study considered both traditional marketing and social media marketing with a key objective of examining the impacts of marketing strategies on the level of growth and performance of SME's in Ghana. A total of 363 SME's was sampled from a population of 900 SME's in the Eastern region of Ghana using qualitative and quantitative methods of data collection. It was revealed at the end of the study that there is a positive relationship between marketing strategies and SME performance with more specific emphasis on social media marketing. It was also revealed that $55.3 \%$ of the population preferred social media marketing due to no costs of advertisement with Facebook being the most preferred website.

April Rust and Mina Evans are both small companies in the clothing industry of Ghana with 9 and 5 employees respectively driven with an aim of establishing international recognition. A case study of these two firms conducted by Woka (2014) revealed a lot about social media advertisement, trust, and organizational growth. Responses from the two firms are explained under the themes of reach, achievements, advertising costs, and duration of exposure. In terms of reach, social media has enabled these firms access a wider range of customers both locally and internationally and has made customers feel closer to the brand and know how to wear it. Mina Evans had 5,965 likes and 2,278 followers on Facebook and Instagram respectively; while April Rust ha 17,135 likes and 1,130 followers on Facebook and Instagram respectively as at 2013 (Woka, 2014). Through social media advertisements, brand awareness has been created for these firms. In relation to achievements, social media advertisements have helped their brands to be internationally recognized and won them awards and nominations. Both firms confirmed the allocation of no advertising costs on social media which means social media advertisements are cost free. Traditional advertisements last as long as fees as paid; however, the reverse is the true for social media adverts (Woka,2014).

\section{Consumer versus Organizations expectations of Social media Advertisement}

Understanding the importance of the method of advertising and the rise of social media makes it key to explore what consumers expect to see in social media adverts and how organizations perceive it (Haida and Rahim,2015). This enables organizations to get a resolution between their corporate objectives and customers' requirements. Research has also shown that, while some organizations believe in using spams and entertaining social media adverts to attract customers, it rather irritates them and they most often ignore the ads (Haida and Rahim,2015); focusing more on an informative and value-based social media advertisement which in turn creates product awareness is the way to go.

In the same vein, Haron (2015) stressed the importance of credibility, hedonic, and informativeness of social media adverts in order to elicit a positive response from consumers.

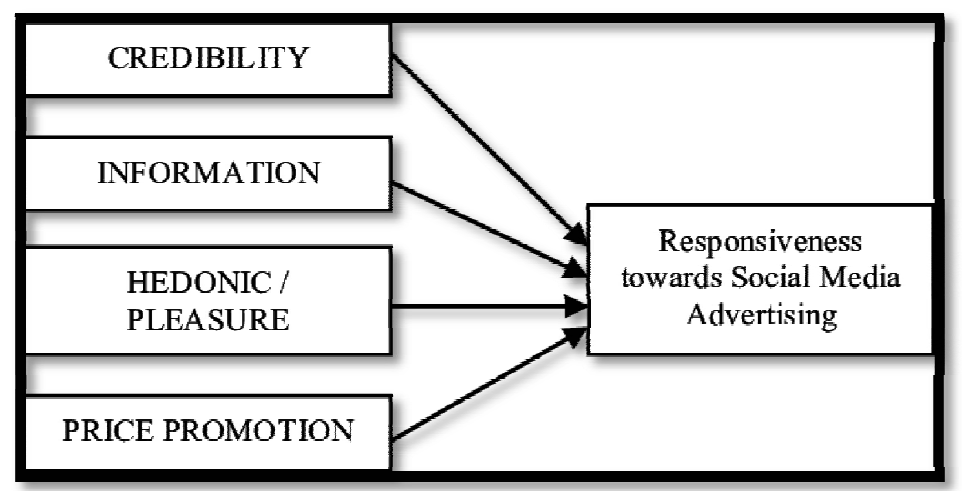

Figure 2: Contents of Social Media Adverts for Positive Consumer Response Source: Haron ,2015

The above model sets a strong foundation for organizations to win more customers and mosey into profit maximization. Fishbein (2018) elucidates that, the mere trend of billions of social media users does not guarantee a company more customers and profit through online ads: this is because even some multinational companies have taken wrong steps in using social media. He further asserts that the three main expectations of consumers on social media adverts are easy for any organization to meet. Consumers expect honesty, friendliness, and helpfulness.

A careful study of literature shows the same expectations of consumers irrespective of industry hence organizations must shift from creating fun alone and be credible.

\section{Effectiveness of Social Media as a Tool for Advertisement}

Social media has proven to a large extent as an effective tool for marketing. Stelzner (2014) emphasizes two main benefits of social media which points to the fact of its effectiveness. Organizational exposure and creating traffic are the main benefits: According to Stelzner's report,92\% and $80 \%$ of marketers confirmed positive feedback on exposure and traffic respectively. 
Social media enhances market strategy and boosts organizational growth except if it is not used properly, lacks focus, or has poor content (Agwu and Carter,2014). However, Bacon (2011) proposes four critical areas for organizations to focus on while marketing on social media. They include, content, skills, engagement, and, consistency.

In addition to the above, companies have used social media to build great market intelligence and customer loyalty (Colliander and Dahlen,2011) which indicates improved sales hence higher profit margins.

\subsection{Major Platforms of Social Media Advertisement}

Social media has risen at a neck breaking speed with the development of several platforms for users to connect. Stelzner (2014) reports that among all social media platforms Facebook is used by $92 \%$ marketers which is followed by Instagram (66\%): all marketers acknowledge Facebook as a very important platform for advertisement. Not only has Facebook been found dominant but also it has been described as the most important social media platform for advertisement: according to Stelzner's 2014 report, 49\% of marketers believe their Facebook marketing is effective and helping make an impact. These statistics can be attributed to the fact that Facebook has many subscribers.

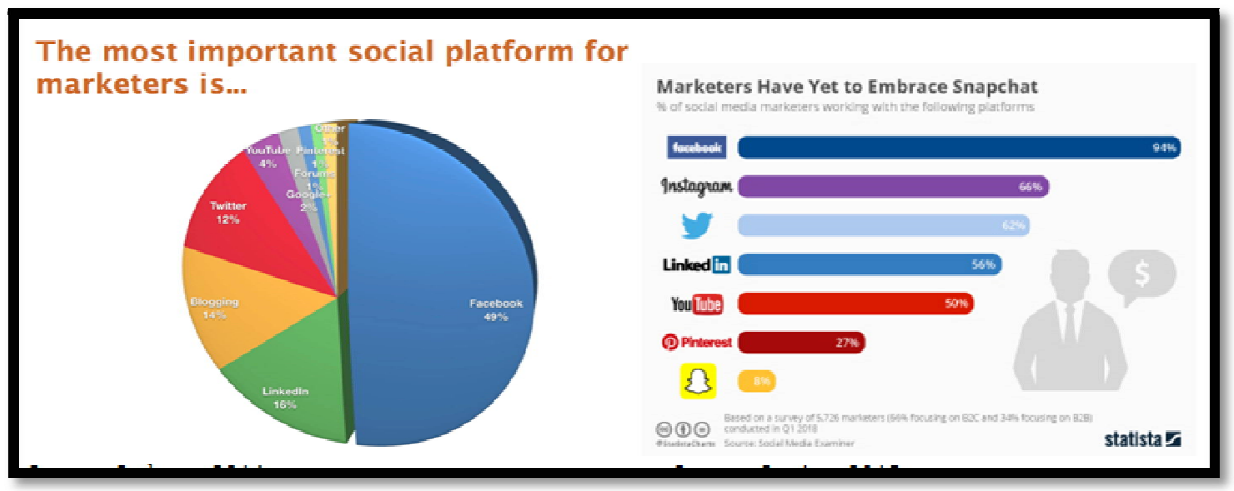

Figure 3: Most Effective Platform for Social Media Advertisement

Source: Stelzner, 2014

Source: Statista, 2018

\section{Recommended Social Media Advertising Strategies for Organizational Growth and Profitability in Ghana}

A strategy is defined as a plan underpinned by already made decision: forming business strategy involves an interaction between the internal and external business environment and some important organization processes. A strategy is viciously subjected to change in different situations (Mintzberg, 1978).A social media advertising strategy must have clear cut objectives, a target audience and the needed resources (Dutta,2010), and of course a system to measure its performance (Wilson et al,2011).Social Media practitioner, experimenter, transformer, and champion are proposed by Wilson et al., (2011) as social media strategies but there still remain no single clear definition of social media adverts. From this background, we can define social media advertisements as an action plan with specific objectives that drives the attainment of specific company goals and as well determine best practices.

It is recommended for Ghanaian firms to note that, in building social media advertising strategy, they must put three main factors; engagement with stakeholders, branding, and learning from new sources at the center of their modus operandi since these have been found to be the main drivers of social media marketing (Dutta,2010). Companies must engage with stakeholders to strengthen social relationships which build trust and translate into exposing the brand to the public. Learning from new sources is critically important as it equips companies with first-hand knowledge on technology trends and issues; hence leveraging on it to identify potential benefits to the business. Through learning, companies can identify the most used social media platforms in order to channel their adverts appropriately and draw attention to their brand.

The literature confirms that, Facebook has the highest number of subscribers followed by Instagram in Ghana. To take full advantage of these, there must be clearly defined goals and action plans. After putting these in place, a business must encourage public participation and interaction online (extrinsic motivation), be constantly creative to improve social media usage (proprietary technologies), generate content on regular and provide feedback to customers on real time basis (Wilson et al, 2011).

The need for feedback is reinforced by the media richness theory (MRT) which is also defined from the perspective of immediacy of feedback. Kahai and Cooper (2003) found that richer media that allows multiple cues and immediate feedback makes communication clear.

To elucidate further, firms must use social media to build brand identity, trust and reputation first before being used to sell products and generate income (Awareness,2012). This way, firms can connect with potential customers on personal basis rather than business basis only.

All the above recommended strategies have been put together into a single diagrammatic model to guide corporate social media advertisements in Ghana. 


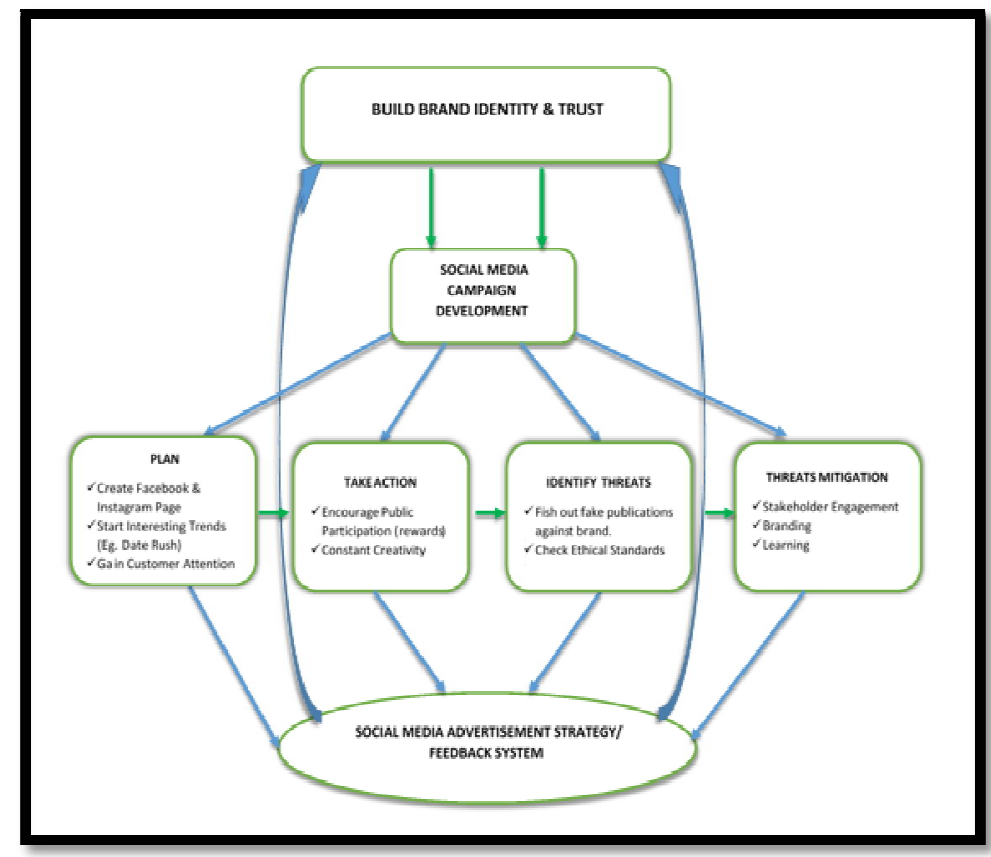

Figure 4: Proposed Social Media Advertisement Model for Ghanaian firms Source: Researcher's Own Construct, 2020

\subsection{Discussion}

This section presents a systematic discussion of how the above model can enhance the online marketing prowess of Ghanaian firms in winning trust and hence growing in profitability; the first critical step to take enough time to build brand identity and earn the trust of netizens. It is important to stress that, no form of commercial activity like selling and making profits must be prevalent at this stage (Awareness, 2012). Once this is achieved, social media campaign can be launched for the business. This campaign should be done in two phases as shown in the model: planning and action phase. The planning phase involves creating a page on Facebook and Instagram which have the highest numbers of subscribers in Ghana and starting an interesting trend by posting viral videos about issues that has gotten the attention of many. For example, TV3 network of Ghana hosted date rush a few months ago and this got the attention of many netizens who would click on any link containing the caption 'date rush'. This strategy will not only bring traffic to the page but also grow brand identity. Now action must be taken based on the plans: based on the model, this can be done through encouraging public participation and being constantly creative.

To encourage public participation, companies can create challenges about their product and place a reward on whoever wins. This may include quizzes about general topics and home recorded dance competitions among others. Creativity means always keeping up with the trends to increase number of visitors to the page and converting them into customers. While doing all this, it is important to engage stakeholders, learn from new sources, and build a strong brand (Dutta,2010).

It is critical for firms to look out for threats in the stages of planning and taking action and use stakeholders, a strong brand, and learning as strategies to mitigate threats like false publications to tarnish brand, copyright issues, and all other issues concerning code of ethics. The media richness theory deepens the importance of providing feedback for the purpose of measuring how well the advertisement strategy is performing (Kahai and Cooper, 2003). Hence, companies must put in place robust systems to receive customer feedback and promptly respond to and solve their needs. Putting the above recommended strategies in place will go a long way to first build a strong brand and trust and finally translate into organizational growth and profitability.

\section{Conclusion}

The main focus of this paper is on unravelling the dynamics of social media marketing and online trust building on organizational growth and profitability. The paper evaluated the trends of social media marketing as well as the threats against brands in and out of the business environment; and of course, the opportunities that are involved. A critical empirical analysis of theories and cases informed the formulation of a novel model to enhance social media advertisements. This model comprehensively provides a strong basis to identify, analyze, and mitigate threats and as develop further strategies to enhance organizational growth and profitability hinged on trust and a strong brand. At the end of the study it is revealed that social media has contributed an essential element to online marketing more than any digital tool has ever offered; hence companies who are able to find novel and effective ways to catch audience attention and instantly convert platform visitors to customers by means of conversation and brand promotion are able to secure a leading market position over competitors. It is also found that Facebook is the leading platform for effective adverts in Ghana followed by Instagram and Twitter respectively. From the above analysis and elucidations, it is justifiable to conclude that the underpinning drivers of social media adverts to yield organizational growth and profitability are engagement with stakeholders, branding, and learning. 


\section{References}

i. Ajami, R., Ramadan, N., Mohamed, N. \& Al-Jaroodi, J., 2011. Security Challenges and Approaches in online Social Networks: A survey. International Journal of Computer science and Network Security, 11(8).

ii. Ajami, R., Ramadan, N., Mohamed, N. \& Al-Jaroodi, J., 2011. Security challenges and approaches in online social networks: a survey. International Journal of Computer Science and Network Security, 11(8), pp. 1-12.

iii. Anderson, J. \& Rainie, L., 2014. The Future of the Internet: Net Threats. Pew Research Center's Internet and American Life project.

iv. Argwu, M. \& Carter, A., 2014. Mobile Phone Banking in Nigeria: Benefits, problems, and Prospects. International Journal of Business and Commerce, Volume 3, pp. 50-70.

v. Aslam, M. H., Shahzad, K., Syed, A. \& Ramish, A., 2013. Social Capital and knowledge sharing as determinants of academic performance. Journal of Behavioral Application Management, 15(1), p. 25.

vi. Awareness, 2012. Social Commerce Lessons: The 6 Social Principles That Increase Sales. [Online]

vii. Available at: http://info.awarenessnetworks.com/Social-Commerce.html

viii. [Accessed 13 May 2020].

ix. Bacon, J., 2011. The Impact of Social Media on Marketing Industry. Fourth Source.

x. Baruah, D., 2012. The Effectiveness of Social Media as a tool of Communication and its potential for Technology enabled connections: A micro level study. International Journal of scientific and Research Publications, 2(5).

xi. Belanche, D. \& Casaló, L., 2015. Rebuilding public trust in government administrations through e-government actions. Revista Española de Investigación en Marketing ESIC,, 19(1), pp. 1-11.

xii. Bertot, J. C., Jaeger, P. T. \& Hansen, D., 2012. The impact of polices on government social media usage: Issues, challenges, and recommendations. Government Information Quarterly, 29(1), pp. 30-40.

xiii. Bertot, J., Jaeger, P. \& al, e., 2012. Promoting Transparency and accountability through ICTs, social media, and Collaborative e-government- Transforming Government: People, Process, amd Policy. Maryland: Emerald Printing.

xiv. Blackwell, R., Miniard, P. \& Engel, J., 2001. Consumer Behavior. Harcourt: Harcourt College Publishers.

xv. Bodnar, K., 2010. Generating Small Business Customers with Social Media Marketing. Small Business Case Studies.

xvi. Boyd, D., 2011. Social Privacy in Networked Publics: Teens' Attitudes, Practices, and Strategies.

xvii. Boyd, D. E. N., 2008. Social Network Sites: Definition, History, and Scholarship. Journal of Computer-Mediated Communication, Volume 13, pp. 210-230.

xviii. Brown, R., 2009. Public Relations and Social Web: How to use Social Media and Web 2.0 in Communication. London: Kogan Paye.

xix. Buehrer, R., Senecal, S. \& Bolman, P., 2005. Sales Force Technology Usage-reasons, barriers, and support: An exploratory Investigation. Industrial Marketing Management, Volume 34, pp. 389-398.

xx. Calefato, F., Lanubile, F. \& Noveilli, N., 2015. Investigating the Effects of Social Media on Trust Building in Customer-supllier Relationships.

xxi. Carr, N., 2010. The shallows: What the internet is Doing to our Brains, s.l.: s.n.

xxii. Carton, S., 2009. Defining Social Media, s.l.: s.n.

xxiii. Colliander, J. \& Dahlen, M., 2011. Following the Fashionable Friend: The Power of Social Media - Weighing the Publicity Effectiveness Of Blogs versus Online Magazines. Journal of Advertising Research, 51(1), p. 313.

xxiv. Das, T. \& Teng, B., 2004. The risk based view of Trust: A conceptual Framework. Journal of Business and Psychology, 19(1), pp. 85-116.

xxv. Dutta, S., 2010. What's Your Personal Social Media Strategy?. In: Harvard Business Review. Havard: Harvard Business School Publishing Corporation, pp. 1-5.

xxvi. Dzisi, S. \& Ofosu, D., 2014. Marketing Strategies and the Performance of SMEs in Ghana. School of Business and Management Studies -Koforidua Polytechnic. European Journal of Business and Management, 6(5).

xxvii. Ebert, T., 2009. Facets of Trust in Relationships- A literature Synthesis of Highly Ranked Trust Articles. Journal of Business and Management, Volume 3, pp. 65-84.

xxviii. Edosomwan, S., Prakasan, S., Kouame, D. \& T, S., 2011. The history of Social Media and its Impact on Business. The Journal of Applied Manageent and Entrepreneurship, 16(3), pp. 79-91.

xxix. Everett, C., 2010. Social media: opportunity or risk?. Computer Fraud \& Security, Volume 6, pp. 8-10.

xxx. Faraj, S., Jarvenpaa, S. L. \& Majchrzak, A., 2011. Knowledge collaboration in online communities. Organization Science, 22(5), p. 1224-1239.

xxxi. Fernandes, D. et al., 2014. Security issues in cloud environments: A survey. International Journal of Information Security, 13(2), pp. 113-170.

xxxii. Flavian, C., Gurea, R. \& Orus, C., 2019. Feeling Confident and Smart with Webrooming: Understanding the Consumer's Path to Satisfaction. Journal of Interactive Marketing, Volume 47.

xxxiii. Gallaugher, J. \& Ransbotham, S., 2010. Social media and customer dialog management at starbucks. MIS Quarterly Executive, 9(4), pp. 197-212.

xxxiv. Gefen, D., Karahama, E. \& Straub, D., 2003. Trust and TAM in online Shopping: An integrated Model. MIS Quarterly, 27(3).

xxxv. Grazia, M., Teresa, M., Finan, S. \& Fennel, C., 2015. Trsut-Building through Social Media communication in Disasater Management. Florence,Italy, International world wide web conference.

xxxvi. Haida, A. \& Rahim, H., 2015. Social Media Advertising Value: A Study on Consumer's Perception. International Academic Research Journal of Business and Technology, 1(1), pp. 1-8. 
xxxvii. Hakansson, P., 2015. Social Media and Trust- A systematic Review. Journal of Business and Economics, 6(3), pp. 517-524.

xxxviii. Hamalainen, A., 2015. Trust Antecedents in Social Networking Services. Alto University School of Business.

xxxix. Haron, H., 2015. Consumer Responsiveness Towards Social Media Advertisements. Hong Kong, International Conference on Management Engineering and Information Technology Application (MEITA 2015).

xl. Hennig-Thurau T., H., F., C. \& .C, H., 2013. Marketing the Pinball Way: Understanding How Social Media Change the Generation of Value for Consumers and Companies. Journal of Interactive Marketing, Volume 27, pp. 237-241.

xli. Hofacker, C. \& Belanche, D., 2018. Eight Social Media Challenges for Marketing Managers. Spanish Journal of Marketing, Volume 20, pp. 73-80.

xlii. Holsapple, C. \& Singh, M., 2001. The knowledge chain model: Activities for competitiveness. International Journal of Expert Systems , 20(1), pp. 77-98.

xliii. Hsu, M., Chang, M. \& Yen, C., 2011. Exploring the antecedents of trust in virtual communities. Behaviroal Information Technology, 30(5), pp. 587-601.

xliv. Hutchings, C., 2012. Commercial use of Facebook and Twitter-risks and rewards. Computer Fraud \& Security, 2012(6), pp. 19-20.

xlv. Icha, O. \& Agwu, M., 2015. Effectiveness of social media marketing on Organizational performance. Journal of Internet Banking and Commerce, 21(1), pp. 1-7.

xlvi. Isaacs, D., 2014. Social Media and Communication. Journal of paediatrics and Child health, Volume 50, pp. 421-422.

xlvii. Joshi, K., Chi, L., Datta, A. \& Han, S., 2010. Changing the Competitive Landscape: Continuous Innovation through ITbased Knowledge Capabilities. Information Systems Research, 21(3), pp. 472-495.

xlviii. Junco, R., Heiberger, T. \& Loken, E., 2011. The Effects of Twitter on college students engagement and grades. Journal of Computer Assisted Learning, 27(2), pp. 119-132.

xlix. Kahai, S. \& Cooper, R., 2003. 'Exploring the Core Concepts of Media Richness Theory: The Impact of Cue Multiplicity and Feedback Immediacy on Decision Quality. Journal of Management Information Systems, 20(1), p. 263-299.

l. Kaplan, A. \& Haenlein, M., 2010. Users of the world, unite! The challenges and opportunities of Social Media. Business Horizons, 53(1), pp. 59-68.

li. Kapoor, K., Tamilmani, K., Rana, N. \& Patil, P., 2017. Advances in Social Media Research: Past, Present and Future. Information Systems Frontiers.

lii. Keen, A., 2007. The Cult of the Amateur. London: Nicholas Brealey.

liii. Kelly, L. \& Gerr, G. D. J., 2010. Avoidance of Advertising in Social Networking Sites. Journal of Interactive Advertising, 10(2), pp. 16-27.

liv. Kim, A. \& Ko, E., 2011. Do social media marketing activities enhance customer equity? An empirical study of luxury fashion brand. Journal Of Business Research, 65(10), pp. 1480-1486.

lv. Kitchenham, B. et al., 2009. Systematic Literature reviews in Software Engineering- A systematic literature review. Information and software Technology, 5(1), pp. 7-15.

lvi. Koranteng, F. \& Wiafe, I., 2018. Factors that promote Knowledge Sharing on Academic Social networking sites: An empirical Study. Education Information Technology, pp. 1-26.

lvii. Korenich, L., Manrai, L. \& Manrai, A., 2013. Social Media: Past, Present and Future. Routledge Companion on the future of marketing, pp. 234-249.

lviii. Lorenzo, C. R., Constantinides, E. \& Alarcón del Amo, M., 2013. Social media as marketing strategy: An explorative study on adoption and use by retailers. Advanced Series in Management, Volume 11, pp. 197-215.

lix. Lucas Jr, H. et al., 2013. Impactful Research on Transformational Information Technology: An Opportunity to Inform New Audiences. MIS Quarterly , 37(2), pp. 371-382.

lx. Macnamara, J. \& Zerfass, A., 2012. Social Media Communication in Organizations: The Challenges of Balancing Openness, Strategy, and Management. International Journal of Strategic Communication, 6(4), pp. 287-308.

lxi. Ma, J., Mehmet, A. \& Sattar, A., 2009. Theories of Trust for Communication Protocols. Automatic and Trusted Computing, pp. 230-248.

lxii. Manning, J., 2014. Definition and Classes of Social Media. In: Encyclopedia of Social Media and Politics. s.l.:Sage Publications, pp. 1158-1162.

lxiii. Marken, G., 2007. Social Media: The Hunted can Become the Hunter. Public Relations Quarterly, 52(4), pp. 9-11.

lxiv. Mayer, C., Davis, J. \& Schoorman, D., 1995. An Integrative Model of Organizational Trust. Academy of Management Review, 20(3), pp. 709-734.

lxv. Mayfield, A., 2006. What is Social Media. Spannerworks.

lxvi. McEvily, B., Perrone, V. \& Zaheer, A., 2003. Trust as an Organizing Principle. Organization Science, 14(1), pp. 91103.

lxvii. McKnight, D., Carter, M., Thatcher, J. \& Clay, P., 2011. Trust in specific technology: An investigation of its components and measures. ACM Transactions on Management Information Systems, 2(2), pp. 1-25.

lxviii. Mcknight, D., Chordury, V. \& Kacmar, C., 202. The impact of initial consumer trust on intentions to transact with a web site: a trust building model. Journal of Strategic Information Systems 1, Volume 11, p. 297-323.

lxix. Mintzberg, H., 1978. Patterns in Strategy Formation. Management Science, 24(9), pp. 934-948.

lxx. Mir, I. \& Zaheer, A., 2012. erification of Social Impact Theory Claims in Social Media Context. Journal of Internet Banking and Commerce, 17(1), pp. 1-15. 
lxxi. Moorman, C., Deshpandé, R. \& Zaltman, G., 1993. Factors Affecting Trust in Market Research Relationships. Journal of Marketing, 57(1), pp. 81-101.

lxxii. Morgan, R. \& Hunt, S., 1994. The Commitment-trust theory of relationship marketing. Journal of Marketing, 58(3), pp. 20-38.

lxxiii. Nyambu, E., 2013. Influence Of Social Media Marketing On Performance Of Telecommunication Firms In Kenya. International journal of Innovative Research, 2(9).

lxxiv. Okeeffe, G. \& Clarke, P., 2011. The Impact of Social Media on Children, Adolescents, and Families. Pediatrics, Volume 127, pp. 800-804.

lxxv. Parveen, F., 2012. Impact Of Social Media Usage On Organizations. Malaya, PACIS .

lxxvi. Picazo-Vela, S., Gutiérrez-Martínez, I. \& Luna-Reyes, L. F., 2012. Understanding risks, benefits,and strategic alternatives of social media applications in the public sector. Government information Quarterly, 29(4), pp. 504511.

lxxvii. Putnam, R., 2000. Bowling Alone: The Collapse and Revival of American community. New York: Touchstone.

lxxviii. Rheingold, H., 1993. The Virtual Community: Homesteading on the Electronic Frontier. s.l.:MIT Press.

lxxix. Rothstein, B., 2003. Social afallorochtillitions Problem. Stockholm: SNS For log.

lxxx. Savolainen, T., 2011. Leadership by Trust in renewing human intellectual Capital. Unipress, pp. 117-141.

lxxxi. Stelzner, M., 2014. How Marketers are using social Media to grow their business: Social Media Marketing Industry Report, s.l.: Social Media Examiner.

lxxxii. Talpau, A., 2014. Social Media- A New way of communication. Series V: Economic Sciences, 7(56).

lxxxiii. Thackeray, R., Neiger, B., Hanson, C. \& McKenzie, J., 2008. Enhancing promotional strategies within social marketing programs: use of Web 2.0 social media. Health Promotion Practice , 9(4), pp. 338-343.

lxxxiv. Tung, J., 2012. A study of Product Innovation on firm performance. International Journal of Organizational Innovation, 4(3), p. 84.

lxxxv. Uslaner, E., 2002. The Moral Foundations of Trust. Cambridge: Cambridge University Press.

lxxxvi. Van DijCK, J., 2013. The Culture of Connectivity. A Crit-ical History of Social Media. New York, NY, USA: Oxford University Press.

lxxxvii. Van Dijck, J. \& Poell, T., 2013. Understanding Social Media Logic. Media and Communication, Volume 1, pp. 2-14.

lxxxviii. Veil, S., Buehner, T. \& Palencher, J., 2011. A Work-iniprocess Literature reviwe: Incorporating Social media in risk and crisis communication. Journal of contingencies and crisis management, 19(2), pp. 110-122.

lxxxix. Warren, A., Sulaiman, A. \& Jafaar, N., 2015. Understanding Civic engagement behavior on Facebook from a Social capital Theory perspective. Behavioral Information Technology, 34(2), pp. 163-175.

xc. Wilson, H., Guinan, P., Parise, S. \& Weinberg, B., 2011. What's Your Social Media Strategy. Harvard: Harward Business Review.

xci. Woka, E. A., 2014. SOCIAL MEDIA ADVERTISING FOR MICRO AND SMALL ENTERPRISES IN GHANA : A case study on the advertising strategies of April Rust \& Mina Evans; brands, Accra: Ashesi University College.

xcii. Wood, J. \& Khan, G., 2016. Social Business Adoption: An empirical Analysis. SAGE Journals.

xciii. Yadav, M., Valck, K., Hennig-Thurau, T. \& L, D., 2013. Social Commerce: A contingency Framework fo assessing Marketing potential. Journal of Interactive Marketing, 27(4).

xciv. Yao, L., Sutton, S. \& Chan, S., 2009. 'Wealth creation from information technology investments using the EVA. The Journal of Computer Information Systems, 50(2), pp. 42-48. 